\title{
Building economic multipliers, rather than measuring them: Community-minded ways to develop economic impacts
}

\author{
Special JAFSCD Issue \\ Economics of Local Food Systems: \\ Utilization of USDA AMS Toolkit Principles \\ Sponsored by \\ FOOD SYSTEMS \\ COLORADO STATE UNIVERSitY

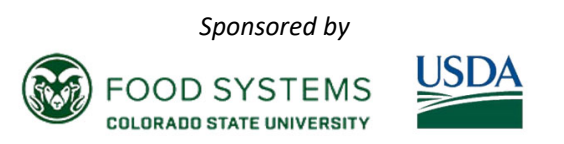

\author{
Megan Phillips Goldenberga* \\ New Growth Associates \\ Ken Meter ${ }^{b}$ \\ Crossroads Resource Center
}

Submitted April 5, 2018 / Revised June 26, August 9, and September 6, 2018 / Accepted September 6, 2018 /

Published online January 23, 2019

Citation: G oldenberg, M. P., \& Meter, K. (2019). Building economic multipliers, rather than measuring

them: Community-minded ways to develop economic impacts. Journal of A griculture, Food Systems, and

Community D evelopment, 8(Suppl. 3), 153-164. https:/ / doi.org/ 10.5304/ jafscd.2019.08C.010

Copyright @ 2019 by the Authors. Published by the Lyson Center for Civic Agriculture and Food Systems. Open access under CC BY license.
Abstract
As co-authors of the USD A Agricultural Marketing
of I-O modeling is the understanding that the
Service's (AMS) Economics of Local Food Systems various sectors of an economy are linked-an output from one sector may be an input to Toolkit featured in this special issue, we pose the question of whether standard input-output (I-O) modeling approaches are appropriate for use in community foods work. In this reflective essay, we discuss the underlying data used in the most common assessment tools and suggest that they are not precise enough for estimating the impacts of emergent small local food firms amid rapidly changing contexts, even when modified following generally accepted methodologies. Since the basis
a * C orresponding author: Megan Phillips G oldenberg, Principal Partner, New Growth Associates, and Associate, Crossroads Resource Center; 781 West Michigan Avenue; Saline, Michigan 48176 USA; +1-906-869-0372; megan@newgrowthassociates.com
b Ken Meter, President, Crossroads Resource Center; 7415 Humboldt Avenue S.; Minneapolis, Minnesota 55423 USA; +1-612-869-8664; kmeter@ crcworks.org another - we are proposing approaches that make these community linkages more visible to food system practitioners. We wish to advance the idea that placing the focus on how communities build robust multipliers may be a better use of resources than generating multiplier calculations that hold questionable value. We suggest that methodologies derived from social network analysis (SNA) will prove increasingly useful in the impact(s) discussion.

\section{Disclosures}
G oldenberg and Meter were both paid as members of a team of authors of the original U.S. D epartment of Agriculture, Agricultural Marketing Service's (USD A AMS) Economics of Local Food Systems Toolkit. Goldenberg and Meter are both consultants paid by organizations utilizing economic, business, and social network analysis as means for furthering food systems and economic development. 


\section{Keywords}

Community D evelopment, Community-Based Food Systems, Economic D evelopment, Social Network Analysis, Economic Impact Analysis, Economic Multipliers, Supply Chains, Value Chains, Value Networks, USD A Local Food Systems Toolkit

\section{Introduction}

Increased interest in local food systems over the last two decades has sparked investment in infrastructure and market development. This development has occurred at the consumer level (forward investments in community supported agriculture farms), the regional level (development of food hubs), and the institutional level (farm-to-institution programs). Economic impact analysis is often viewed as the essential tool for gauging the importance of these food systems investments. G overnment officials seek guidance in making development decisions and rely largely on commercially available input-output (I-O) models for weighing costs versus benefits and return on investment of development projects and programs.

While impact studies vary greatly in their approach and methodology, their conclusions are almost always the same: investments in local food systems yield positive economic impacts (Conner, Knudson, Hamm, \& Peterson, 2008; Gunter \& Thilmany, 2012; Hughes, Brown, Miller, \& McConnell, 2008; Hughes \& Isengildina-Massa, 2013; Mullinix et al., 2016; Tuck, Haynes, King, \& Pesch, 2010; ). Y et the magnitudes of these impacts and the methodologies used to derive them are a topic of debate. It is also not clear which types of food systems initiatives render the best returns on investment. Results can vary widely depending on the locale, the quality and quantity of the data available, the assumptions made, the different scenarios modeled, and the validity of the approach taken (Crompton, 2006).

Indeed, one strong motivation for producing the Economics of Local Food Systems Toolkit (Thilmany McFadden et al., 2016) was increasing criticism of the extent to which local food systems initiatives produce economic and community benefits, and how those impacts are determinedalong with lingering concerns about whether economics should even be the primary tool for measuring success (O ’Hara \& Pirog, 2013).

Our intention in this essay is to provide practical guidance to community food practitioners while expanding the general discussion of impacts. We wish to emphasize that economic impact estimation can be a valuable tool in certain settings, but is not necessarily appropriate or adequate for community food systems work. In this essay, we use the term "multiplier" to mean economic multipliers.

We begin by offering a theoretical overview highlighting key strengths and limitations of economic impact modeling. We highlight a core insight that drives modeling: that local economic actors are linked. Expanding upon this understanding, we identify ways of making these community linkages more discernable to community members through visible representations, and we show there is an economic value to these connections. We report on the results of using this approach in partnership with economic developers. Finally, we offer an introduction to social network analysis (SNA), a methodology we are using to help community foods practitioners understand how to strengthen community multipliers. We give examples of this approach by summarizing research commissioned by a county food systems initiative, and we suggest that tools from SNA, including network mapping and showing how commercial networks are constructed, may prove increasingly useful in enhancing and in some instances reframing the food systems discussion.

Theoretical Basis for E conomic Impact A ssessments and Resulting M ultipliers

To establish a theoretical basis, we begin by clarifying one definition. The term "economic impacts" is regularly misused in common discourse. O ften the term is misleadingly used to identify "spending" (e.g., an expense to a school and revenue for a producer; an output) rather than the "impact of spending." For example, one might hear a school nutrition director describing the economic impact of a farm to school program in terms like this: "We made an impact of US $\$ 200,000$ in new food purchases." A more technical definition of "impacts" would focus on how this expenditure rippled 
through the local economy to create new jobs or personal income, as in, "O ur investment of US $\$ 200,000$ to buy local foods created an additional US\$63,000 of income for local residents." In this example, the US\$200,000 initial input is considered the direct impact, whereas the US\$63,000 additional income is an indirect and/ or induced impact, and the total impact is US\$263,000, assuming these purchases did not displace existing local food trade.

To estimate these additional impacts (beyond initial spending), an economic impact assessment is needed. The most commonly used and commercially available models follow the same basic linear I-O approach and are considered the standard for economic development and capital investment discussions. They are typically applied to large firms or major industries operating in specific regions; they were not developed to assess small and hyperlocal impacts, which are more typical of local food systems activities.

The basis of I-O modeling is understanding that sectors of an economy are linked: an output from one sector may be an input in another sector (for example, a farm may produce carrots that are washed, diced, frozen, and packaged by a nearby firm, and these may in turn be purchased by a school lunch program). Any change in an economy will have effects that are both direct (the farm sells carrots) and indirect (new jobs are created at the food processor). Furthermore, new jobs at the processing facility will lead to increases in household income, which in turn may lead to additional jobs in a service sector (medical personnel, for example) and increased local spending by employees (induced effects).

Impact calculations are often posed as an economic "multiplier." A multiplier is a measure of how many times a dollar earned in a given geographic area cycles through that locale before it leaves. For example, if an economic impact assessment (EIA) focuses on jobs, it might estimate the ratio of new jobs that will be created by an investment of a certain amount compared to employment found under prevailing economic conditions.
To think about this in a more abstract way, a multiplier is the ratio of new outputs to new inputs.

At minimum, a multiplier must be 1.0. Such a result would mean that each dollar of new revenue leaves the community immediately. Tribal reservations often have multipliers close to one since so few goods and services are produced internally. If a given locale's multiplier were 2.0, this would mean that for each dollar of new revenue, one additional dollar is spent at other local businesses- a total of two dollars. A region of small farms and businesses that buy many of their essential goods and services from each other, and are closely connected socially, might enjoy multipliers as high as 2.6 (Swain, 1999; and personal communication, Feb. 12, 2001; Swain \& Kabes, 1998), although this may only be a historical phenomenon given that the recent integration of the global economy has limited regions' abilities to produce for themselves. In the farm-toschool example presented at the beginning of this section, the output multiplier would be 1.3 (US\$263,000/ US\$200,000).

Practical L imitations to Common A pproaches No economy can be fully modeled, since all models are inherently simplifications while economies are exceedingly complex. Simplifying assumptions must be made to make any calculations at all. For example, I-O models assume perfect supply and demand. ${ }^{1}$ That is to say, for example, the modeling assumes that when demand for fresh fruits and vegetables increases, supply increases to meet this demand without prices changing. This is a faulty assumption, particularly in regard to local food systems. Locally produced food items can often be substituted by easily available produce (grapes may come from the farm next door, California, or Chile, or may be replaced by eating bananas from Costa Rica). ${ }^{2}$

A similar issue involves price differentials: if local farmers charge a premium for their products, consumers are free to turn to grocery stores for cheaper alternatives. Very few studies discuss the importance of price in their evaluation of food systems impacts, but some studies account for it

${ }^{1}$ The technical term for this assumption is "market clearing conditions."

2 Many I-O experts attempt to account for these complexities by modifying standard data sets. 
directly. Tuck, Haynes, King, and Pesch (2010) specifically address the issue of prices in their modeling of several farm-to-school scenarios, in which they adjust the model by raising tax rates as one way to account for increased food prices due to buying locally.

Furthermore, I-O models assume that unlimited supplies of inputs (e.g., raw materials, fuel, or subcomponents) are available. Real-life constraints on input supplies (such as land, water, and soil fertility) mean that actual impacts may be smaller than standard I-O models project. This is a recurrent theme in local and regional food systems assessments; consumers may wish to purchase more food from local farms, but land or water access costs are often prohibitive for a starting farmer to bear. There are often harsh limits to the pool of skilled or willing labor available, or to the infrastructure required to process and distribute foods within the community.

IMPLAN ${ }^{3}$ an I-O model developed at the University of Minnesota, is by far the most commonly used model for EIA. This is because it is relatively affordable and straightforward to use. It is the model most likely to be taught in academic settings and used in governmental decision-making. Moreover, advanced users are able to alter the underlying structure of the modeled economy, the data, and the manner in which impacts are calculated (D eller, Hoyt, Hueth, \& Sundaram-Stukel, 2009). Accordingly, many consulting firms have adapted IMPLAN to create proprietary models. The USD A AMS Toolkit devotes considerable attention to customizing this base model.

O ther common EIA methodologies are more complex and involve simulating the workings of an economy that is changing over time (economic simulation models, or ESMs). These models include computable general equilibrium (CGE) models and others. To ensure that the strengths of more complex economic modeling are not overlooked here, we offer a brief summary of these. These are discussed more fully in Lynch et al. (2015) and Goldenberg and Colasanti (2017).

ESMs include most aspects of linear I-O models and add even more features. They try to account for complexity, rather than being limited to simpler (linear) relationships. These can be used to estimate changes over a longer period of time and allow for more dynamic aspects of an economy to also change (such as prices). They are necessarily more complicated, requiring more time and resources to build, and sophisticated computer software programs to execute. As such, these are not as readily available or financially accessible as stand-alone I-O models. These models are also more difficult to customize.

Overall, I-O models such as IMPLAN are not only easier to use and construct, but they are also more generous in their results than CGE or econometric models. This means that practitioners and politicians alike often prefer the conclusions of I$\mathrm{O}$-based impact estimates, even if those estimates cannot be verified and will never be actualized.

Still, our core concerns are somewhat deeper. However refined these quantitative methodologies, and however useful I-O may prove when analyzing relatively stable larger industries and regional economies, the underlying I-O data used in the most common economic impact assessment tools are not precise enough for estimating impacts for emergent small food firms at the local level. This is true even if modified following the most advanced methodologies, as outlined in the USD A AMS Toolkit.

Typically, the data underlying I-O models are derived from state or national data sets. The "local share" is estimated by dividing these counts by population or regional income shares (G oldenberg \& Colasanti, 2017; Lynch et al., 2015). While useful as broad approximations, these data are neither fine-grained enough to closely reflect actual local economic exchange, nor can they account for emerging local food firms that have sprung up since national data sets were compiled, or firms that are too small to show up in broader samples.

Practitioners often attempt to offset these limitations by gathering suitable local data through primary research. However, even when excellent data can be compiled from local firms, the ultimate modeling calculations rely heavily upon industry averages. For example, when a local food firm sells

3 The acronym stands for "Impact Analysis for Planning." 
to a wholesaler, modeling software still assumes the wholesaler conforms to industry averages unless the wholesaler has also supplied original data. This continues up the supply chain.

We also note that IMPLAN multiplier calculations do not include estimates of error. O ften results are presented to several decimals despite the limits of the underlying data mentioned above, giving readers a misleading impression of accuracy and precision (Lynch et al., 2015).

Finally, and perhaps most importantly from a community development perspective, the results of an I-O based analysis have limited utility to community practitioners and stakeholders because the calculation process is often viewed as a "black box," using modeling equations that are not readily understood by community members or even systems-level stakeholders (Meter, 2011). The very people being studied seldom understand how I-O results were derived, although they are often asked to provide sensitive data to modelers and then to accept findings on faith.

Due to the complexity and cost of prevailing EIA models, a very real practical issue surfaces when considering the use of economic models in community foods contexts: Should scarce resources be allocated to economic impact modeling and modifying conventional models, or to building the foundation of local food trade? We suggest that community food systems practitioners across the U.S. have a limited need for traditional economic impact analysis, as stated above. We recommend that technical assistance professionals add alternative methodologies to their approach lest localfood-systems-as-economic-development strategies lose all credibility. ${ }^{4}$

A Signal in the N oise: C onsiderations and A lternatives for Interpreting the $\mathrm{V}$ alue of $\mathrm{M}$ ultipliers At its core, a multiplier is a measure of the local economic context and its level of connectivity. The more that local firms and residents are interconnected and trading goods and services with each other, the longer a dollar is likely to cycle through the region, and the higher the multiplier. The same business (or investment) placed in different settings may yield quite different multipliers. Thus the crux of any impact assessment is not necessarily "how is output affected by a change to input?" but rather, "what are the strengths and weaknesses of the linkages active in the underlying economy?"

Thus the prevailing emphasis on measuring and quantifying economic multipliers is often misplaced. Because strong linkages are essential for strong multipliers, the emphasis should be placed on building larger multipliers by nurturing the growth of dozens of independent yet interconnected small businesses owned by local residents, and to foster local purchasing of locally produced goods and services. ${ }^{5}$ In general, when a sector consists of larger firms, local multipliers (positive local economic impacts) are smaller (Swain, 1999; and personal communication, Feb. 12, 2001; Swain \& Kabes, 1998).

Economic approaches that measure economic progress strictly from the perspective of the firm, or of the national economy, often overlook this reality. Attempting to create greater efficiencieswhen viewed strictly from these perspectives- may indeed generate considerable surplus value ${ }^{6}$ that can be diverted to what is often considered a "higher use" 7 (Lynch et al., 2015). Y et from the perspective of those communities, or their business networks, that have contributed to the creation of this surplus value without gaining financial reward, such a shift in resources amounts to an extraction of potential wealth (Hassebrook, 2006; Meter, 1990, 2003). Thus agricultural regions have adopted labor-saving technology in a devoted effort to promote national efficiencies, despite the

\footnotetext{
${ }^{4}$ In his 2006 paper, Crompton discusses how the practice of analyzing tourism events has lost its integrity since assumptions are not based on reality and projected impacts are not realized. He further wonders if tourism events themselves have any credibility in the eyes of community leaders after a decade of these questionable practices.

5 This is endemic to the definition of a local economic multiplier. See also Goldschmidt (1978).

${ }^{6}$ Surplus value is created through selling a given good or service that either exceeds the actual costs of production including labor, or that generates a consumer surplus by being priced at less than what consumers would be willing to pay.

${ }^{7}$ While the authors do not necessarily subscribe to this concept, it is often assumed by prevailing economic theories that larger economic units can make better use of surplus value than can households or smaller firms.
} 
fact that their children and neighbors need employment opportunities (Heffernan, 1999). In the process, rural youth have become "exports" to metropolitan areas (Meter, 1999, 2001). Moreover, although farmers have doubled total-factor productivity since 1969, net cash income from farming nationally has remained constant or declined when inflation is taken into account (Meter, 2004; USD A Economic Research Service, 2012, 2013). The only exceptions have been when external shocks drove short-lived commodity price spikes in 1973, 1979, and 2010-2012.

Additionally, extractive economic structures diminish the potential to create local wealth by removing resources from rural and inner-city locales. This has consequences not only for each locale, but also for the national economy (Carr \& Kefalas, 2009). When local economic engines are weakened, labor availability and productive skills decline, and stored capital may be diverted to maintaining income flows, rather than toward new productive capacity (Meter, 2006). This creates a downward spiral in which resources increasingly flow to metropolitan areas, while draining rural communities (Carr \& Kefalas, 2009; Meter, 1983, 1990, 2001; National Farmers Union of Canada, 2012). In recent years, political resentment toward financial centers has erupted in regions that felt undervalued compared to metro centers, leading to great political division and legislative stasis (Cramer, 2016).

\section{The Economic Value of Connectivity}

The driving force, and indeed the competitive advantage, of community-based food systems is relational trading - what some call "sticky" relationships. Examples are commerce based on mutual loyalties (community supported agriculture models that reduce farmer risk; slow money investments with reduced expectations of return; or differentiation and branding based upon personal, regional, mode of production [e.g., fair trade, organic, or sustainable], cooperative ownership, or other loyalties). Such transactions are not accounted for by conventional economic modeling, which assumes consumers are isolated and determined to increase individual economic benefits. Moreover, such sticky transactions are often marginalized by economic approaches that promote national efficiencies over regional capacity-building.

Recognizing relational commerce also helps broaden the impacts discussion beyond pure economics. Sociologist Cornelia Flora, in particular, has developed and applied a "resource capital paradigm" that lists human connectivity as one of seven forms of "capital," including natural, human, cultural, financial, built, and political capital (2004). While some people may recoil at the idea of having their social interactions considered a form of capital, placing social interactions and community commitments within a resource framework may help certain audiences understand the importance of social connectivity.

Economically speaking, the productive benefits of social capital are enormous. Research attributes many positive outcomes to stronger social capital: reductions in transaction costs (Putnam, 2000; Rydin \& Holman, 2004; Sabatini, 2009); career success, product innovation, reduced turnover rates, entrepreneurship, and learning (Adler \& Kwon, 2002); reduced high school dropout rates (Coleman, 1998); and higher rural quality of life (Peters, 2017). Further, an individual's or firm's place within a network can predict certain rates of innovation (Powell, Koput, \& Smith-D oerr, 1996), financial success (Shipilov \& Li, 2008), better jobs and faster promotions (Burt, 1992), and societal power and influence (Brass, 1984).

At a community development level, civic engagement is strongly correlated with economic development. In fact, in his study of Italy, Putnam argues that civic engagement is not a function of wealth, but instead that economic development and effective government are consequences of social connectivity and capital (1993). Since the economic multiplier is a measure of how many times a dollar "turns over" inside a given geography before leaving, one would expect that the stronger the sense of community connectedness, the greater the likelihood that financial transactions will cycle money among community members (Meter, 2011).

This evidence suggests that local economic development is correlated with, if not also dependent upon, community development and social connectivity (social capital). It is, therefore, 
possible to make a solid case for estimating economic impacts by measuring connectivity, particularly in regards to local food systems development, where so much is predicated on social connections and community commitments.

\section{Measuring Connectivity and Showing How to Strengthen Multipliers Through Network Analysis}

Although the authors of this essay inserted language into the Toolkit introducing SNA as an alternative methodology for assessing economic impacts, resource constraints meant this theme could not be fully developed in the first edition. SNA assesses the extent and strength of relationships in a given network. However, there are very few studies, to date, using SNA to focus on economic relationships, and very little support for characterizing and increasing social capital as a development strategy.

The primary components of an SNA are linkages and nodes, where nodes represent individual people or entities (such as a business or a website) and linkages are the relationships between any two nodes. These can be portrayed both qualitatively, as a map of network connections, or quantitatively, as analytics. For example, estimating which nodes offer the strongest connectivity, calculating how efficiently information can be transmitted through the network, or estimating the closeness of the connections across the network are all possible outcomes of an SNA.

SNA practitioners typically focus on three dimensions for assessing the strength of network interactions:

(1) D oes this social or commercial connection involve financial exchange?

(2) D oes the respondent routinely share information with this connection?

(3) Would the respondent turn to this connection when advice or support is desired? (Goldenberg \& Colasanti, 2017; P. Ross, personal communication, July 4, 2013)

If questions are well crafted, researchers may learn a great deal about the degree to which feelings of trust and respect are reciprocated in a given network.

D ata are collected largely first-hand, through surveys and interviews, and then the study team determines the resulting metrics using software that quantifies the character of network relationships (Borgatti, 2002; Borgatti, Everett, \& Freeman, 2002). Likely indicators include total spending inside and outside of the defined region, number of suppliers and number of customers inside and outside the defined region, relative size of those various accounts, plus any number of social indicators, such as trust, commitment, and reciprocity, and which entities trade with other entities or do not. Simply viewing a network map can lend significant insights into how to leverage relationships to open up additional markets or supply chains. O ne may learn that a seemingly wellconnected person is only weakly trusted, or vice versa (D unne \& Shneiderman, 2013). Possible pathways for competition and/ or collaboration also become visible (Klimas, 2015).

Furthermore, because SNA extends beyond financial exchanges, it gives voice to many of the visions and values that underlie local food systems work in the first place. By making social and commercial networks visible, SNAs help illuminate the mechanisms by which economic multipliers are built.

A pplications of $\mathrm{N}$ etwork A nalysis In northeast Indiana, economic development officials in an 11-county region sought assistance as they constructed a regional local foods network. Past experience had led these developers to lose interest in economic impact calculations. Pursuing business-clustering strategies, they had worked diligently for more than two and a half years to engage commodity farmers and processors in collaborating to expand value-added opportunities. In the meantime, the manufacturers lost interest in the discussions, viewing each other as competitors for national markets. A consultant was brought in to suggest alternative strategies. After interviewing several innovative farmers who grow food for regional markets, the connections they had built with household consumers were documented. One farm had assembled 5,200 addresses in its e-mail 
list, delivering food orders directly to 45 locations. When mapped (see Figure 1), these drop sites showed that locally oriented farmers had effectively built collaborations even as manufacturers refrained from participating, suggesting that strengthening such internal networks offered robust development opportunities (Meter, 2016).

When economic developers viewed these maps, they instantly saw both the strengths and gaps in these farmer networks. These farms were highly profitable because they had adopted intensive production methods and built strong support among consumers with expendable incomes. Yet the map also made clear that the farmers' main customers lived in the metro areas of Chicago, Detroit, and Indianapolis, rather than nearby Fort Wayne. The developers saw that farmers had already built robust business networks that the developers had overlooked by considering farms as outsiders to local business circles. As a result, the developers opted to partner with local farmers, and also to pay greater attention to urban residents, especially in lowerincome areas.

In this case, mapping a network produced strong strategic insights, showing where connectivity already existed and where it still needed to be built. While much simpler than a full-fledged SNA, this exercise provided solid insights to developers seeking to strengthen local economic exchange.

This work in northeast Indiana laid the foundation for extending the application of SNA to economic impact discussions. In early 2018, we successfully applied SNA in Maricopa County, Arizona, in collaboration with Paula Ross, a retired researcher from the University of Toledo. We worked at the request of the Maricopa County Food Systems Coalition, which asked us to document the growth in social and commercial networks that has resulted from community foods work. We performed detailed interviews with 33
Figure 1. Map of the Commercial Network of Delivery Sites Developed by Seven Sons Farm near Fort Wayne, Indiana

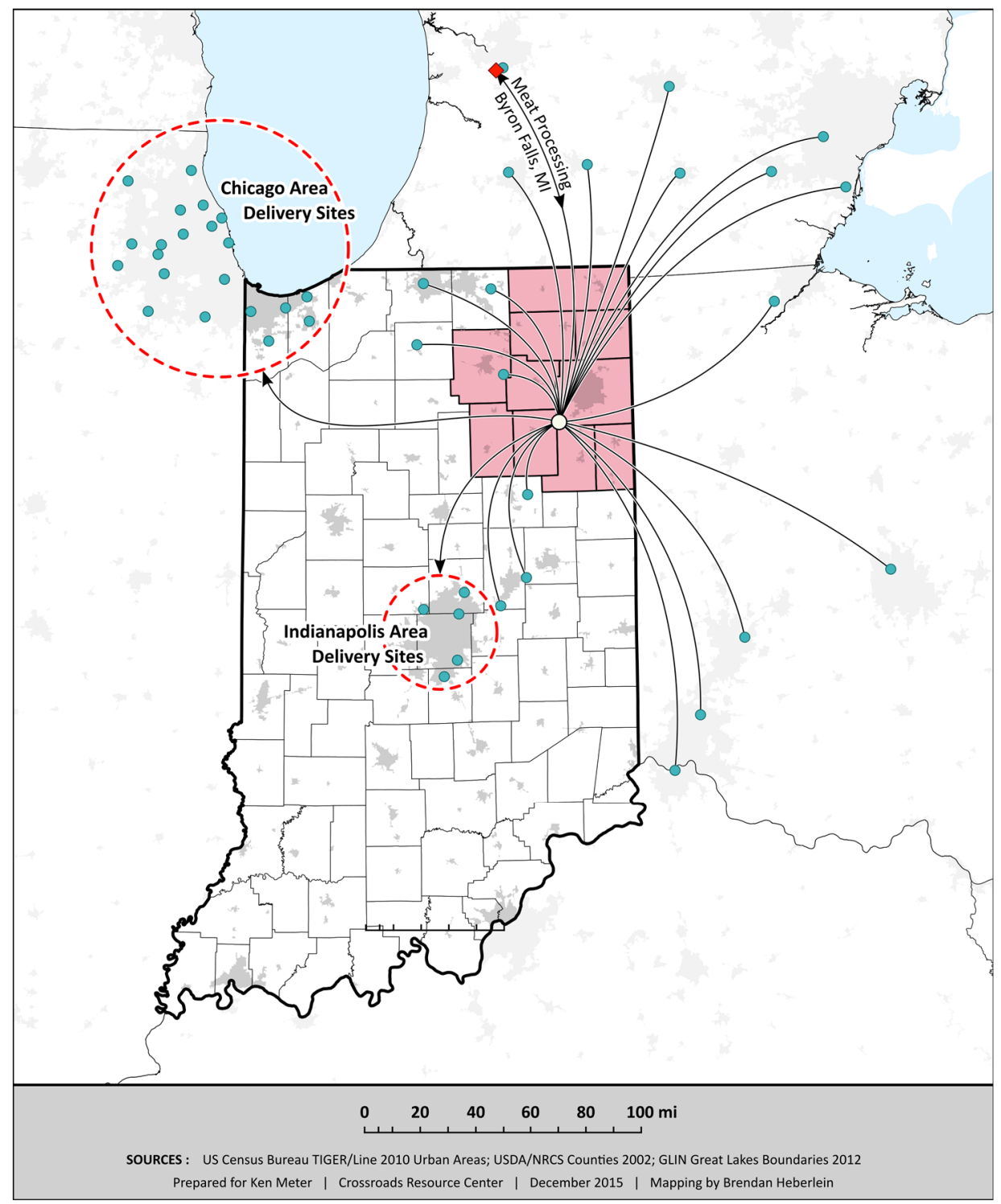


food system practitioners selected by the council, asking each interviewee to name the five individuals or firms they turned to most for information, advice, or financial trade. The resulting network maps show clearly that farmers who raise food for local markets are relatively isolated from civic leaders, policy discussions, and each other (Meter, Goldenberg, \& Ross, 2018). By layering these network maps, we illustrated how local stakeholders could bring farmers into stronger commercial networks. The maps showed that food buyers and nonprofits play key roles in connecting farmers to a broader public and marketplace, and that farmer organizations played a limited role in connecting farmers to social or commercial networks in this marketplace.

Enthusiastically received by Maricopa County Food Systems Coalition members, these network maps formed the basis for strategic recommendations on how to build local food trade, thus building local economic multipliers. In this individual study, we determined that the network maps themselves were more valuable than their associated quantitative calculations. In part, this is because these quantitative calculations are determined through opaque methodologies based on insufficient primary data (echoing our concern about I-O calculations). Thus, our reporting only contained the network maps.

\section{Conclusions and Recommendations}

The limitations and costs of performing comprehensive economic modeling, and the lack of transparency inherent in software-generated calculations, suggest that alternative approaches that are easier to measure, comprehend, and communicate will be highly valuable to economic impact discussions at a local level.

When models do not accurately reflect the realities local practitioners face or the values that motivate their work, this leads to heightened concern (from the perspective of local firms or community members) that the money spent modeling might be better spent in actually building the local food system until its size justifies modeling. This is especially true since, in these early stages of development, any dollar allocated to performing assessments is a dollar that could have been spent launching local foods initiatives. In our experience, the most useful and inexpensive way to help groups (1) establish stronger linkages that actively create higher economic multipliers and (2) build infrastructure that creates local efficiencies in local food trade is to make social and commercial networks more visible.

While the USD A AMS's Toolkit acknowledges the need to consider additional values and benefits beyond economic growth, it concluded that alternative methodologies and evaluations were beyond its scope. This essay offers one opportunity to expand that discussion. While SNA is currently a difficult concept for many economic developers or investors to embrace, our professional experience suggests this is an important discussion to open up.

As one research team that used the Toolkit put it, the most valuable question on the data collection survey was about how the study partners could best support the farmers' work. They added that by "dedicating a lot of energy to capturing economic impact assessment data, it became clear that there's more to it [food systems development] than that, economic impacts is an inferior way to measure values. You don't measure all the outcomes of policy work with just economic impact assessments" (J. Weiland \& M. Rahe, personal communication, March 2017). Placing more emphasis on additional outcomes, such as social connectivity, and creating additional toolkits to evaluate and improve them is a logical next step for food systems development leaders.

Transparency is also key to building trust among community members. This is the most significant element in building lasting communitybased food systems. When local residents can easily procure organic produce from a nearby superstore, it is primarily their dedication to, and trust in, local farms that encourages them to pay upfront for a CSA share, or to purchase food at a farm stand, even if farm gate prices are higher. Showing how networks are constructed and helping leaders to both strengthen this collaboration and build economic exchange are a faster path to building trust - and even to building multipliers - than accepting quantitative data from a black box. Thus we have begun challenging developers to think differently about estimating local economic impacts. 


\section{References}

Adler, P. S., \& K won, S.-W. (2002). Social capital: Prospects for a new concept. A cademy of M anagement Review, 27(1), 17-40. https:// doi.org/ 10.5465/ amr.2002.5922314

Borgatti, S. P. (2002). Netdraw Software for Network Visualization. Lexington, KY: Analytic Technologies.

Borgatti, S. P., Everett, M. G., \& Freeman, L. C. (2002). Ucinet6 for Windows: Software for Social Network Analysis. Lexington, KY: Analytic Technologies.

Brass, D. J. (1984). Being in the right place: A structural analysis of individual influence in an organization. A dministrative Scienœ Q uarterly, 29(4), 518-539. https:// doi.org/ 10.2307/ 2392937

Burt, B. S. (1992). Structural holes: The social structure of competition. Cambridge, MA: Harvard University Press.

Carr, P. J., \& Kefalas, M. J. (2009). H ollowing out the middle: The rural brain drain and what it means for A merica. Boston: Beacon Press.

Coleman, J. S. (1988). Social capital in the creation of human capital. A merican Journal of Sociology, 94, S95-S121. https:/ / doi.org/ 10.1086/ 228943

Conner, D. S., Knudson, W. A., Hamm, M. W., \& Peterson, H. C. (2008). The food system as an economic driver: Strategies and applications for Michigan. Journal of $\mathrm{H}$ unger \& E nvironmental N utrition, 3(4), 371-383. http:/ / dx.doi.org/ 10.1080/ 19320240802528849

Cramer, K. J. (2016). The politics of resentment: Rural consciousness in W isonsin and the rise of Scott W alker. Chicago Studies in American Politics. https:// doi.org/ 10.7208/ chicago/ 9780226349251.001.0001

Crompton, J. L. (2006). Economic impact studies: Instruments for political shenanigans? Journal of Travel Research, 45(1), 67-82. https:// doi.org/ 10.1177/ 0047287506288870

Deller, S., Hoyt, A., Hueth, B., \& Sundaram-Stukel, R. (2009). Research on the economic impact of cooperatives. University of Wisconsin Center for Cooperatives, Madison, WI. Retrieved from http:/ / reic.uwcc.wisc.edu/

Dunne, C., \& Shneiderman, B. (2013, April). Motif simplification: Improving network visualization readability with fan, connector, and clique glyphs. In Procedings of the SIG C H I Conference on H uman F actors in Computing Systems (pp. 32473256). Paris: ACM. https:// doi.org/ 10.1145/ 2470654.2466444

Flora, C. B., \& Flora, J. L., with Fey, S. (2004). Rural communities: L eyacy + dhange (2nd Ed.). Boulder, CO: Westview Press.

Goldenberg, M. P. \& Colasanti, K. (2017). T ools for assessing economic impact: A primer for food system practitioners. New Growth Associates, LLC, \& Michigan State University Center for Regional Food Systems. Retrieved from https:/ / www.canr.msu.edu/ resources/ tools-for-assessing-economic-impact-a-primer-for-food-system-practitioners

Goldschmidt, W. (1978). A s you sow: Three studies in the social onsequenœes of agribusiness. Montclair, N.J.: Allenheld, O smun.

Gunter, A., \& Thilmany, D . (2012). Economic implications of farm to school for a rural Colorado community. Rural Connections, 6(4), 13-16.

Hassebrook, C. (2006). What the family farm crisis looks like: Factors contributing to the current situation and building a national agenda for change. In K. Mullinix (Ed.), The next agriaultural revolution: R evitalizing family-based agrialture and rural communities (pp. 23-31). Yakima, Washington: G ood Fruit G rower.

Heffernan, W. (1999). C onsolidation in the food and agrialture system. University of Missouri-Columbia: Report to National Farmers Union, Feb. 5.

Hughes, D. W., Brown, C., Miller, S., \& McConnell, T. (2008). Evaluating the economic impact of farmers' markets using an opportunity cost framework. Journal of A gricultural and A pplied E conomics, 40(1), 253-265. Retrieved from http:/ / purl.umn.edu/ 45523

Hughes, D. W., \& Isengildina-Massa, O . (2013, April). The impact of a buy local agriculture campaign on the South Carolina economy. Presentation at the 52nd Southern Regional Science Association Annual Meeting, Arlington, Virginia.

Klimas, Patricia. (2015). The structural face of competition, cooperation and coopetition inside business networks. A rgumenta 0 economica, 1(34) 127-155.

Lynch, J., Meter, K., Robles-Schrader, G., Goldenberg, M. P., Bassler, E., Chusid, S., \& Austin, C. J. (2015). E x ploring economic and health impacts of local food procurement. Chicago: Illinois Public Health Institute. Retrieved from http:// www.crcworks.org/ EHimpacts.pdf 
Journal of Agriculture, Food Systems, and Community Development

Meter, K. (1983). G reen Isle: F eeding the world and farming for the bank er. Minneapolis: Crossroads Resource Center. Retrieved from http:// www.crcworks.org/ gi.pdf

Meter, K. (1990). M oney with roots. Minneapolis: Crossroads Resource Center. Retrieved from http:// www.crcworks.org/ roots.pdf

Meter, K. (2003). F ood for thought: F ood with the farmer's fac on it: E merging community-based food systems (W. K. Kellogg Foundation Media Briefing Paper). Retrieved from https:/ / www.crcworks.org/ fface.pdf

Meter, K. (2004). Finding food in farm country. Presentation to Community Food Security Coalition annual meeting, Milwaukee, O ctober 19. Minneapolis: Crossroads Resource Center. Meter updates this analysis as new data becomes available. Retrieved from http:// www.crcworks.org/ crcppts/ cfsc04.pdf

Meter, K. A. (2006). Evaluating farm and food systems in the U.S. In B. Williams \& I. Imam (Eds.), Systems concepts in evaluation: A n ex pert anthology (pp. 141-159). Point Reyes, CA: EdgePress.

Meter, K. (2011). Learning how to multiply. Journal of A grialture, F ood Systems, and C ommunity D evelopment, 1(2), 9-12. https:/ / doi.org/ 10.5304/ jafscd.2010.012.014

Meter, K. (2016). N ortheast Indiana local foods network. Minneapolis: Crossroads Resource Center and Manheim Solutions for the Northeast Indiana Regional Partnership. Retrieved from http:// www.crcworks.org/ innetworks16.pdf

Meter, K., Goldenberg, M. P., \& Ross, P. (2018). Building community networks through community foods. Minneapolis: Crossroads Resource Center. Retrieved from http:// www.crcworks.org/ azmaricopa18.pdf

Meter, K. \& Rosales, J. (2001). Finding food in farm country. St. Paul: Community Design Center. Retrieved from http:// www.crcworks.org/ ff.pdf

Mullinix, K., D orward, C., Sussmann, C., Polasub, W., Smukler, S., Chiu, C., ... Kissinger, M (2016). The future of our food system: Report on the southwest BC bioregion food system design project. Richmond, British Columbia: Institute for Sustainable Food Systems, K wantlen Polytechnic University. https:/ / doi/ org/ 10.13140/ RG .2.2.22261.37607

National Farmers Union of Canada. (2012, May 26). Farmers, the food chain and agriculture policies in C anada in relation to the right to food. Submission of the $\mathrm{N}$ ational Farmers U nion of Canada to the Special Rapporteur on the Right to F ood, Mr. 0 livier D e Schutter, Mission to Canada, May 2012. Accessed June 16, 2018, at https:/ / www.nfu.ca/ policy/ farmers-the-foodchain-and-agriculture-policies-in-canada-in-relation-to-the-right-to-food/

O'Hara, J. K., \& Pirog, R. (2013). Economic impacts of local food systems: Future research priorities. Journal of A griculture, Food Systems, and Community D evelopment, 3(4), 35-42. http:// dx.doi.org/ 10.5304/ jafscd.2013.034.003

Peters, D. J. (2017). W hat drives quality of life in Iowa small towns? Iowa State University, Rural Sociology (SOC 3082). Retrieved from https:// store.extension.iastate.edu/product/ 15124

Powell, W. W., Koput, K. W., \& Smith-D oerr, L. (1996). Interorganizational collaboration and the locus of innovation: Networks of learning in biotechnology. A dministrative Scienœ Q uarterly, 41(1), 116- 145. https:// doi.org/ 10.2307/ 2393988

Putnam, R. (1993). The prosperous community: Social capital and public life. The A merican Prospect. Retrieved from http:/ / www.prospect.org/ cs/ articles?article=the prosperous community

Putnam, R. D . (2000). Bowling alone: The collapse and revival of A merican community. New York: Simon \& Schuster.

Rydin, Y., \& Holman, N. (2004). Re-evaluating the contribution of social capital in achieving sustainable development. L ocal E nvironment 9(2), 117-133. https:/ / doi.org/ 10.1080/ 1354983042000199561

Sabatini, F. (2009). Social capital as social networks: A new framework for measurement and an empirical analysis of its determinants and consequences. The Journal of Socio-E conomics 38(3), 429-442. https:// doi.org/ 10.1016/j.socec.2008.06.001

Sacks, J. (2002). The money trail: M easuring your impact on the local economy using L M 3. London: New Economics Foundation. Retrieved from http:// www.neweconomics.org

Shipilov, A. V., \& Li, S. X. (2008). Can you have your cake and eat it too? Structural holes' influence on status accumulation and market performance in collaborative networks. A dministrative Scienœ Q uarterly, 53(1), 73-108. https:// doi.org/ 10.2189/ asqu.53.1.73

Swain, L. B. (1999). A study of the economic contribution of small farms to communities- completed 1996 to 1999. Unpublished manuscript. 
Swain, L. B., \& Kabes, D. (1998). 1996 cmmunity supported agriculture report. Unpublished manuscript.

Thilmany McFadden, D ., Conner, D., D eller, S., Hughes, D ., Meter, K., Morales, A., ... Tropp, D . (2016). The economics of local food systems: A toolkit to guide community discussions, assessments, and choios. U.S. D epartment of Agriculture, Agricultural Marketing Service. Retrieved from https:// localfoodeconomics.com/ wpcontent/ uploads/2017/ 03/ Toolkit-D esigned-FINAL-UPDATED-03-7-2017.pdf

Tuck, B., Haynes, M., King, R., \& Pesch, R. (2010). The economic impact of farm-to-school lunch programs: A Central Minnesota ex ample. Minneapolis: University of Minnesota Extension. Retrieved from http:/ / www.farmtoschool.org/ resourcesmain/ the-economic-impact-of-farm-to-school-lunch-programs-a-central-minnesota-example

USD A Economic Research Service. (2012). Part 1: Farm income and balance sheet indicators, 1929 - 2012F, expressed in constant $(2005=100)$ dollars. Farm Balance Sheet series. Retrieved from https:/ / data.ers.usda.gov/ reports.aspx?ID =17835

USD A Economic Research Service. (2013). Table 1. Average Annual Rates of G rowth (\%), 1948-2009. Farm Productivity series. Retrieved from https:/ / academic.oup.com/ view-large/ 122706 